\section{El concepto de autonomía en las teorias de Rawls y Habermas}

María de los Angeles Yannuzzi

María de los Angeles Yannuzzi es Investigadora

y Profesora Titular de Teoría Política I, Escuela de Ciencia

Política, Facultad de Ciencia Política y RRIII,

Universidad Nacional de Rosario.

Vicepresidenta del Consejo de Investigaciones de la UNR.

Dirección Postal: Buenos Aires 1351, $1^{\circ}$ D. 2000 - Rosario

tel: 0341-4219321

e-mail: yannuzzi@agatha.unr.edu.ar

\section{Resumen}

El concepto de autonomía supone un sujeto autorresponsable, autor de sus propias leyes. Es decir que sólo son legítimos aquellos principios que han sido racionalmente aceptados por los ciudadanos, eliminando así todo rasgo de heteronomía. Sin embargo, en el contexto de las sociedades políticas modernas, la noción de autonomía encuentra ciertas dificultades. El hecho mismo de la representación coloca una instancia de mediación que podría llevar a la paradoja de instituir una nueva heteronomía. Esto nos lleva no sólo a reflexionar en torno a la articulación entre la libertad de los modernos y la libertad de los antiguos, sino que, además, nos obliga a plantearnos la relación entre lo particular y lo general, teniendo en cuenta que esto significa pensar la articulación entre lo individual y lo colectivo. En función de ello, dos son las teorías que nos interesa analizar en el presente trabajo: el liberalismo político de Rawls y el republicanismo kantiano de Habermas, ya que ambas retoman el concepto kantiano de autonomía y lo articulan en el plano de la política. Es a partir de ellas que pretendemos definir los alcances del concepto, determinando las dificultades que el mismo plantea en el contexto de ambas teorías.

\section{Summary}

The concept of autonomy supposes a self-responsible subject, author of his/her own laws. This means that only those principles rationally accepted by the citizens are legitimate, removing this way any stroke of heteronomy. However, in the context of modern political societies, this notion of autonomy finds certain difficulties. Representation itself places a request of mediation that could introduce the paradox of establishing a new kind of heteronomy. This makes us analyze not only the articulation between modern liberties and antique freedom, but also the relationship between the particular and the general, taking in account that this means to think on the articulation between the individual and the collective. According to this, two are the theories we pretend to analyze in our present work, Rawls's political liberalism and Habermas's kantian republicanism, since both take the kantian concept of autonomy and they articulate it at the political level. In this context, we pretend to define the theoretical possibilities of the concept, determining at the same time its difficulties within both theories. 